\title{
Ring opening of some 1,1,2-trihalocyclopropanes with a polar substituent attached to C-2; evidence for regioselective attack directed by hydrogen bonding
}

\author{
Bjarte Holmelid, Ole H. Kvernenes, Mari Hodne, and Leiv K. Sydnes* \\ Department of Chemistry, University of Bergen \\ Allégaten 41, NO-5007 Bergen, Norway \\ E-mail: leiv.sydnes@kj.uib.no
}

Dedicated to Professor Torbjörn Norin on the occasion of his $75^{\text {th }}$ anniversary

\begin{abstract}
Selected members of the title family of compounds, prepared from 1,1-dibromo-2-chloro-2diethoxymethylcyclopropane by standard chemical transformations, were dissolved in mixtures of dichloromethane and a protic, nucleophilic reagent and treated with $50 \%$ aqueous sodium hydroxide in the presence of a phase-transfer catalyst, triethylbenzylammonium chloride (TEBA), at room temperature. In all cases except two, regiospecific ring opening of the cyclopropane took place, giving one product formed by nucleophilic attack of the carbon atom to which the polar substituent was attached. This clearly lends support to the notion that hydrogen bonding contributes significantly to direct the attack of protic nucleophiles.
\end{abstract}

Keywords: Halocyclopropanes, ring opening, phase-transfer catalysis, acetylenic ketals, acetylenic acetals, hydrogen bonding

\section{Introduction}

It is well established that 2-substituted 1,1,2-trihalocyclopropanes (1) undergo ring opening and give mixtures of the corresponding acetylenic diethyl ketals (2) and acetylenic diethyl acetals (3) when exposed to $50 \%$ aqueous sodium hydroxide in the presence of an excess of ethanol and some triethylbenzylammonium chloride (TEBA), a phase-transfer catalyst. ${ }^{1-5}$ Mechanistic studies have shown that the reaction under these phase-transfer conditions (PTC) is a multistep process encompassing several dehydrohalogenations and involving a cyclopropene intermediate, the corresponding 1-R-3,3-dihalocyclopropene (Figure 1), which is consumed by nucleophilic attack of ethoxide and ethanol at C-1 and C-2, respectively, affording both ketal and acetal. ${ }^{4,5}$ 


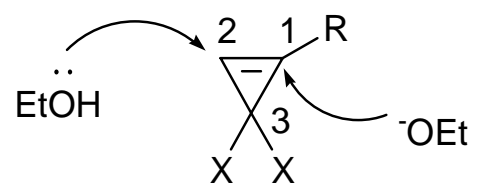

Figure 1. Ring opening of 2-R-substituted 1,1,-dihalo-2-chlorocyclopropane derivatives under PTC in the presence of ethanol occurs via the corresponding 1-R-substituted 3,3dihalocyclopropenes, which are attacked by ethanol and ethoxide as indicated.

It has been established that the nucleophilic attack of the cyclopropene intermediate is sensitive to the steric bulk of $\mathrm{R}$ in such a way that the amount of acetylenic ketal decreases when $\mathrm{R}$ becomes sterically more demanding. ${ }^{6}$ However, one compound that appeared to deviate from this rule, was 1,1-dibromo-2-chloro-2-diethoxymethylcyclopropane (1a) which afforded 3,3,4,4tetraethoxybut-1-yne (2a) as the only product when treated with sodium hydroxide under standard conditions (Scheme 1). ${ }^{7}$ Exclusive formation of this ketal requires regiospecific attack of the cyclopropene intermediate at the carbon atom bearing the polar substituent, and this suggests that the steric repulsion between ethanol molecules and $\mathrm{R}$, the diethoxymethyl moiety, is more then offset by attractive forces due to hydrogen bonding between the same entities.

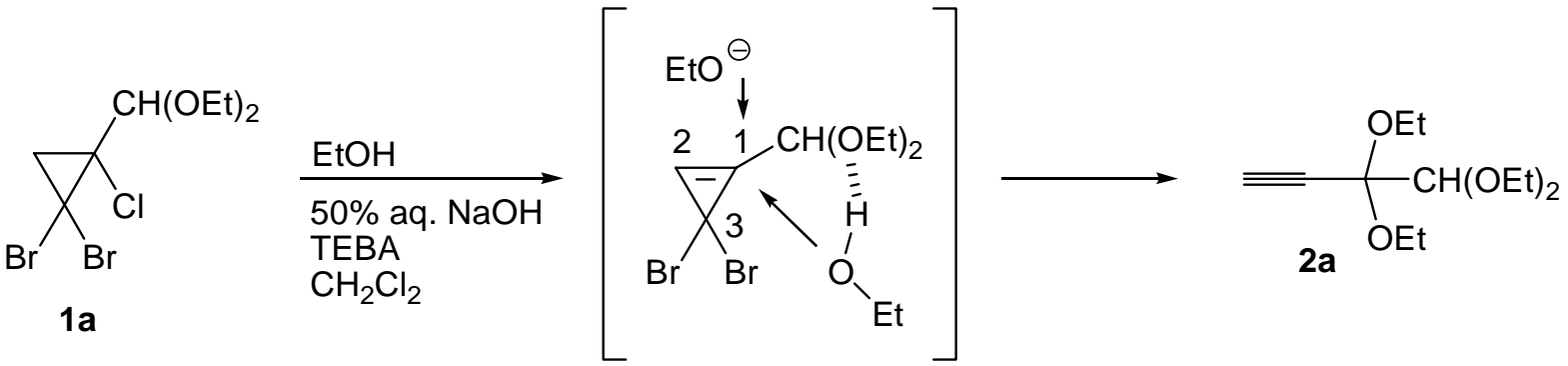

\section{Scheme 1}

It is quite conceivable that this seemingly exceptional case is not really extraordinary, but reflects a general reactivity pattern which remains to be uncovered. We therefore decided to extend the scope of our studies by reacting selected 1,1,2-trihalocyclopropanes with a different polar substituent at $\mathrm{C}-2$ under the reaction conditions employed to convert $\mathbf{1 a}$ to $\mathbf{2 a}{ }^{7}$ and by reacting $1 \mathrm{a}$ in the presence of protic reagents other than ethanol. The results of our investigations are reported here. 


\section{Results and Discussion}

\section{Preparation of cyclopropanes}

Seven 1,1-dibromo-2-chlorocyclopropanes with a polar substituent attached to C-2 were prepared from 1a by well-established synthetic transformations (Scheme 2). Hydrolysis of 1a to give 2,2-dibromo-1-chlorocyclopropanecarbaldehyde (1b) was unsatisfactory with some acids, but when $80 \%$ aqueous formic acid was employed, the corresponding aldehyde was obtained in 91\% yield. Subsequent Jones oxidation of the aldehyde afforded the corresponding 2,2-dibromo1-chlorocyclopropanecarboxylic acid (1c) in very good yield (91\%), and conversion of this acid to the corresponding methyl ester, methyl 2,2-dibromo-1-chlorocyclopropanecarboxylate (1d), was uneventful when 1c was exposed to a mixture of methanol and a catalytic amount of sulfuric acid at elevated temperature.
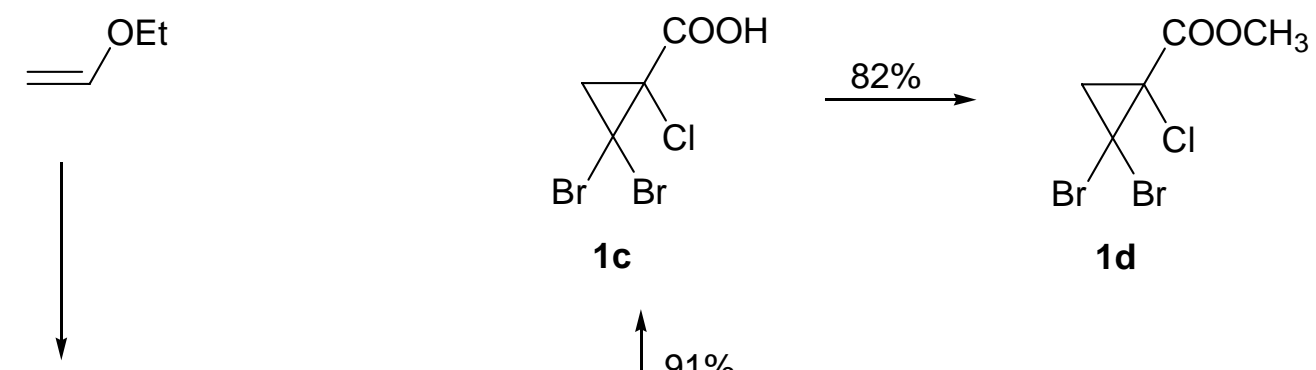

$1 \mathrm{c}$

1d
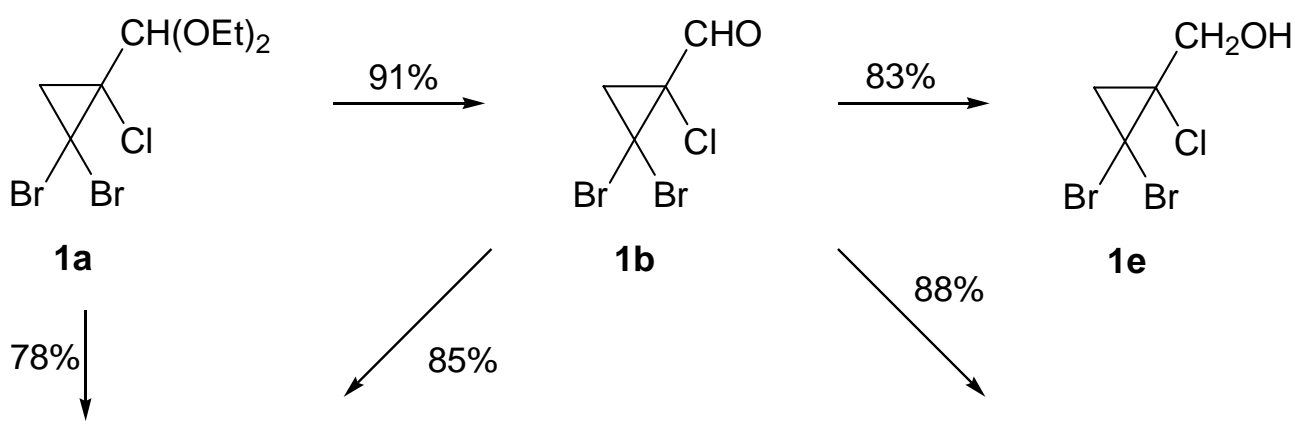

$1 e$

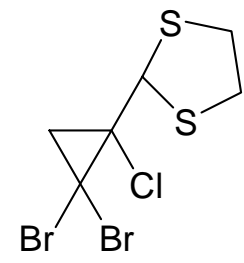

1h

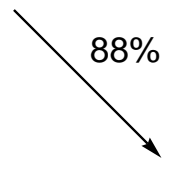

$1 \mathbf{b}$
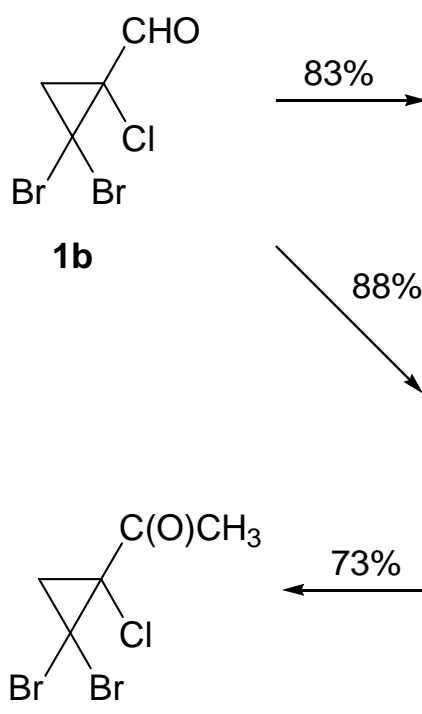

$1 \mathrm{~g}$

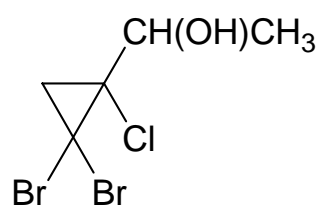

$1 f$

Scheme 2. Structures and yields of cyclopropanes $\mathbf{1 b}-\mathbf{1 h}$ prepared from 1a as described in this paper. The synthesis of 1a from ethyl vinyl ether is described in refs. 7 and 8 . 
Aldehyde $\mathbf{1 b}$ is also an excellent starting material for the preparation of primary and secondary alcohols. When treated with sodium borohydride in ethanol, 2,2-dibromo-1chlorocyclopropylmethanol (1e) was obtained in 83\% yield, and exposure of the same aldehyde to methylmagnesium iodide furnished 1-(2,2-dibromo-1-chlorocyclopropyl)ethanol (1f) in excellent yield $(88 \%)$. It is noteworthy that no product due to reduction of the gem-dibromo moiety was observed in the latter case, since it is well known that this Grignard reagent has the ability to convert similar cyclopropanes to the corresponding monobromides. ${ }^{9,10}$ With $\mathbf{1 f}$ at hand formation of the corresponding ketone, 2,2-dibromo-1-chlorocyclopropyl methyl ketone (1g), was envisaged to take place by a simple Jones oxidation, and this was indeed achieved under standard conditions.

Exploratory experiments with 1a revealed that this cyclopropane could be converted directly to other acetals under various conditions. This reactivity pattern was utilized to prepare a thioacetal, 2-(2,2-dibromo-1-chlorocyclopropyl)-1,3-dithiolane (1h), which was obtained in good yield (78\%) by treating 1a with 1,2-ethanedithiol in the presence of slightly acidic silica gel at room temperature. ${ }^{11}$ The same dithiolane could also be synthesized, with a slightly better yield $(85 \%)$, by reacting aldehyde $\mathbf{1 b}$ with 1,2-ethanedithiol in the presence of boron trifluoride diethyl etherate following a somewhat modified literature procedure. ${ }^{12}$

\section{Ring opening of cyclopropanes 1b-1h under PTC in the presence of ethanol}

Cyclopropanes $\mathbf{1 b}$ - $\mathbf{1 h}$ were treated with sodium hydroxide under the same phase-transfer conditions that were applied when 1a was converted quantitatively to 3,3,4,4-tetraethoxybut-1yne (2a). All the compounds appeared to react under these conditions, and most of them gave one product only, viz. the alkyne analogous to $\mathbf{2 a}$, although there were exceptions, aldehyde $\mathbf{1 b}$ and alcohols 1e and 1f.

The primary alcohol (1e) furnished a 1:1 mixture of terminal alkyne 2,2-diethoxybut-3-yn-1ol (2e), a ketal, and the corresponding internal alkyne, 4,4-diethoxybut-2-yn-1-ol (3e), an acetal (Scheme 3), in a combined yield of $82 \%$, which is lower than that of $2 \mathbf{a}$ from 1a (98\%), but better than what was obtained when most of the other cyclopropanes are reacted under the same conditions (Table 1). The other alcohol, 1f, which is secondary, reacted completely differently from the majority of the cyclopropanes and afforded the internal alkyne, 5,5-diethoxypent-3-yn2-ol (3f) in 85\% isolated yield. Surprisingly enough, not even traces of the terminal-alkyne analogue $2 \mathbf{f}$ could be detected.

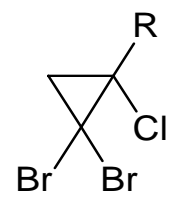

1

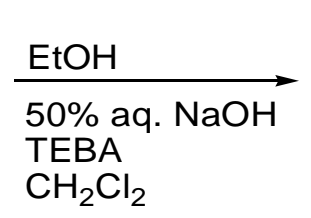

$\mathrm{CH}_{2} \mathrm{Cl}_{2}$

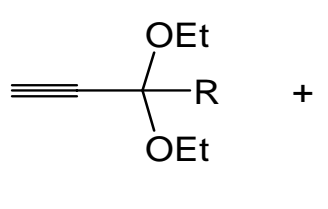

2

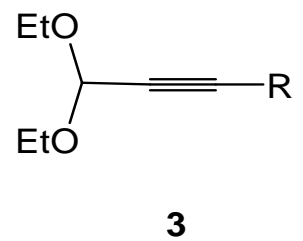

3

Scheme 3. $\mathrm{R}=\mathrm{CH}_{2} \mathrm{OH}(\mathbf{1 e}, \mathbf{2 e}, 3 \mathbf{3 e}) ; \mathrm{R}=\mathrm{CH}(\mathrm{OH}) \mathrm{Me}(\mathbf{1 f}, \mathbf{2 f}, \mathbf{3 f})$. 
Table 1. Ring opening of 1,1-dibromo-2-chloro-2-R-cyclopropanes 1a - $\mathbf{1 h}$ under phase-transfer conditions in the presence of ethanol

\begin{tabular}{cccc}
\hline $\mathrm{R}$ & $\mathbf{1 , 2 , 3}$ & Isolated yield of $\mathbf{2}(\%)$ & Isolated yield of $\mathbf{3}(\%)$ \\
\hline $\mathrm{CH}(\mathrm{OEt})_{2}$ & $\mathbf{a}$ & $96^{\mathrm{a}}$ & 0 \\
$\mathrm{CHO}$ & $\mathbf{b}$ & $0^{\mathrm{b}}$ & $0^{\mathrm{b}}$ \\
$\mathrm{COOH}$ & $\mathbf{c}$ & 39 & 0 \\
$\mathrm{COOMe}$ & $\mathbf{d}$ & 75 & 0 \\
$\mathrm{CH}_{2} \mathrm{OH}$ & $\mathbf{e}$ & 41 & 41 \\
$\mathrm{CHMeOH}$ & $\mathbf{f}$ & 0 & 85 \\
$\mathrm{C}(\mathrm{O}) \mathrm{Me}$ & $\mathbf{g}$ & 75 & 0 \\
$\mathrm{CH}\left[\mathrm{SCH}_{2} \mathrm{CH}_{2} \mathrm{~S}\right]$ & $\mathbf{h}$ & 50 & 0 \\
\hline
\end{tabular}

a Taken from ref. 7 .

${ }^{b}$ All of $\mathbf{1 b}$ was consumed, but neither $\mathbf{2} \mathbf{b}$ nor $\mathbf{3 b}$ could be isolated from the reaction mixture.

Aldehyde 1b reacted much more diversely than the other trihalocyclopropanes and gave a product mixture containing at least 12 compounds as borne out by TLC analyses. IR and NMR spectra of the product mixture indicated the presence of a range of functional groups including conjugated and / or unconjugated alkyne, allene, aldehyde, and ethoxy moieties. Attempts to isolate and purify some of the products by column chromatography were unsuccessful, not only because several of the products had almost the same $\mathrm{R}_{\mathrm{f}}$ value, but also due to the fact that some of the compounds appeared to be unstable and suffered secondary reactions.

If the regiospecificity of the ring opening of 1 were mainly determined by steric influence, the size of most of the R groups in $\mathbf{1}$ is such that formation of the internal alkynes (3) should be favoured. This is not the case; on the contrary, in most cases, viz. 1c, $\mathbf{1 d}, \mathbf{1 g}$ and $\mathbf{1 h}$, acetal $\mathbf{3}$ is not formed at all. This clearly indicates that the $\mathrm{R}$ groups in these four substrates form hydrogen bonds with ethanol that are strong enough to cause the same redirection as the hydrogen bonding between the diethoxymethyl moiety during ring opening of 1a. As a result ethanol attacks the cyclopropene intermediates at C-1 instead of C-2 (see Scheme 1) and affords the corresponding terminal alkynes 2 only.

Although 1e and 1f also contain R groups that can engage in hydrogen bonding with ethanol, both substrates deviate from the pattern outlined above, 1e by giving a mixture of the corresponding alkynes $\mathbf{2 e}$ and $\mathbf{3 e}$, and in the case of $\mathbf{1 f}$, by furnishing the internal acetylene $\mathbf{3 f}$ only. The reason for this behaviour is not clear, but one explanation can be that both compounds are alcohols, whose $\mathrm{OH}$ group can engage in hydrogen bonding with ethanol not only as an electron donor (like 1c, 1d, $\mathbf{1 g}$ and $\mathbf{1 h}$ ), but also as an electron acceptor. This additional hydrogen bond is capable of facilitating ethanol attack at both $\mathrm{C}-1$ and $\mathrm{C}-2$, depending on conformational changes, thus preventing regiospecific ring opening by attack of $\mathrm{C}-2$ to take place (Figure 2). The fact that $\mathbf{1 f}$ gives no $\mathbf{2 f}$ at all whereas 1e affords a reasonable yield of $\mathbf{2 e}$ 
could then be explained by the larger steric crowding of the (hydroxyl)(methyl)methyl moiety as compared to the (hydroxyl)methyl group.
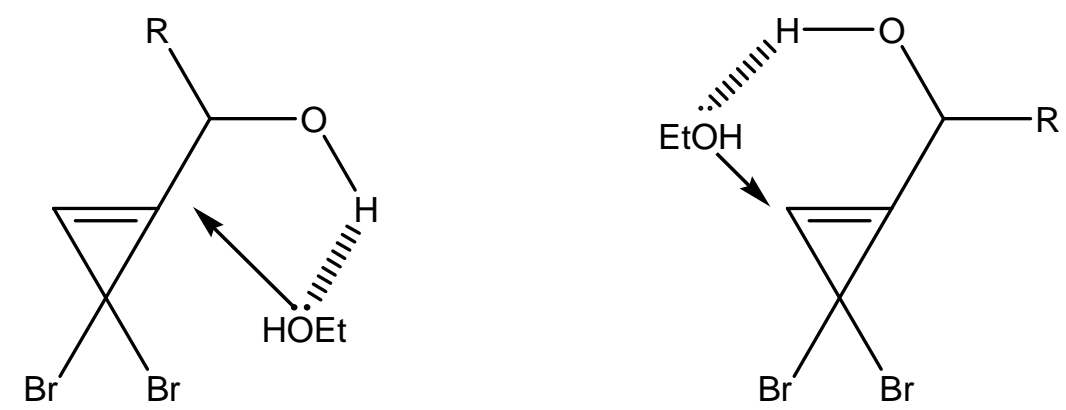

Figure 2. Two extreme conformations of $\mathbf{1 e}(\mathrm{R}=\mathrm{H})$ and $\mathbf{1 f}(\mathrm{R}=\mathrm{Me})$ engaged as electron acceptors in hydrogen bonding with ethanol.

\section{Ring opening of 1a under PTC in the presence of an alcohol or a thiol}

A consequence of the results presented and discussed above is that ring opening of 1,1-dibromo2-chloro-2-diethoxymethylcyclopropane (1a) with $\mathrm{NaOH}$ under phase-transfer conditions in the presence of alcohols other than ethanol should give terminal alkyne only. In order to test the validity of this line of reasoning 1a, dissolved in methylene chloride containing either an alcohol different from ethanol or a thiol, was reacted with sodium hydroxide under the same phasetransfer conditions that were applied when 1a was converted to 2a in quantitative yield. The results, which are summarized in Table 2, exhibit at least two noteworthy trends. Most importantly, when ring opening took place only one alkyne was obtained, viz. 2, the formation of which is facilitated by hydrogen bonding. Secondly, the yield of $\mathbf{2}$ drops as the acidity of the alcohol or thiol drops; thus, whereas methanol gives the corresponding ketal (2i) in quantitative yield, 1a is recovered unchanged when tert-butyl alcohol is employed (Table 2). This very considerable difference in reactivity is closely connected to the hydroxide's ability to convert the alcohols into the corresponding alkoxides; the reaction appears to be unsuccessful with tert-butyl alcohol, but satisfactory with methanol (which furnishes methoxide that generates the reactive cyclopropene precursor to $\mathbf{2} \mathbf{i}$, see Scheme 1) because methanol is far more acidic than tert-butyl alcohol. $^{13}$ 
Table 2. Ring opening of 1,1-dibromo-2-chloro-2-diethoxymethylcyclopropane (1a) under PTC in the presence of an alcohol or a thiol

\begin{tabular}{cccc}
\hline Alcohol or thiol & $\mathbf{2}$ & $\mathrm{X}, \mathrm{Y}$ & Isolated yield (\%) \\
\hline $\mathrm{EtOH}$ & $\mathbf{a}$ & $\mathrm{X}=\mathrm{Y}=\mathrm{OEt}$ & 96 \\
$\mathrm{MeOH}$ & $\mathbf{i}$ & $\mathrm{X}=\mathrm{Y}=\mathrm{OMe}$ & 96 \\
$\mathrm{Me}_{2} \mathrm{CHOH}$ & $\mathbf{j}$ & $\mathrm{X}=\mathrm{Y}=\mathrm{OCHMe}_{2}$ & 39 \\
$\mathrm{Me}_{3} \mathrm{COH}$ & $\mathbf{k}$ & $\mathrm{X}=\mathrm{Y}=\mathrm{OCMe}_{3}$ & 0 \\
$\mathrm{HOCH}_{2} \mathrm{CH}_{2} \mathrm{OH}$ & $\mathbf{l}$ & $\mathrm{X}, \mathrm{Y}=\mathrm{OCH}_{2} \mathrm{CH}_{2} \mathrm{O}$ & 43 \\
$\mathrm{H}_{2} \mathrm{NCH}_{2} \mathrm{CH}_{2} \mathrm{OH}$ & $\mathbf{m}$ & $\mathrm{X}, \mathrm{Y}=\mathrm{O}$ & 42 \\
$\mathrm{HSCH}_{2} \mathrm{CH}_{2} \mathrm{OH}$ & $\mathbf{n}$ & $\mathrm{X}, \mathrm{Y}=\mathrm{SCH}_{2} \mathrm{CH}_{2} \mathrm{O}$ & 51 \\
$\mathrm{HSCH}_{2} \mathrm{CH}_{2} \mathrm{SH}$ & $\mathbf{0}$ & $\mathrm{X}, \mathrm{Y}=\mathrm{SCH}_{2} \mathrm{CH}_{2} \mathrm{~S}$ & 0 \\
\hline
\end{tabular}

The importance of a proper balance between the nucleophilicity and the acidity of the organic protic reactant and its corresponding anion(s) is illustrated by the outcome of the reactions involving 1,2-ethanedithiol and 2-mercaptoethanol instead of a simple alcohol. When exposed to an excess of sodium hydroxide, the dithiol is converted to the corresponding dithiolate, which is an excellent nucleophile, but such a weak base that 1a does not suffer elimination to give the reactive cyclopropene intermediate (Figure 1) involved in the ring-opening reaction. When 2mercaptoethanol is exposed to the same conditions, on the other hand, formation of the corresponding thiolate takes place (because $\mathrm{RSH}$ is much more acidic than $\mathrm{ROH}$ ). This hydroxythiolate is subsequently in part converted to ${ }^{-} \mathrm{SCH}_{2} \mathrm{CH}_{2} \mathrm{O}^{-}$dianion, which is a strong base as well as a good nucleophile. Attack on 1a by the alkoxide moiety affords 3,3-dibromo-1diethoxymethylcyclopropene, which first reacts with the thiolate at $\mathrm{C}-1$ followed by several transformations that ultimately lead to formation of 2-diethoxymethyl-2-ethynyl-1,3-oxathiolane (2n) (Scheme 4) in moderate yield (Table 2).

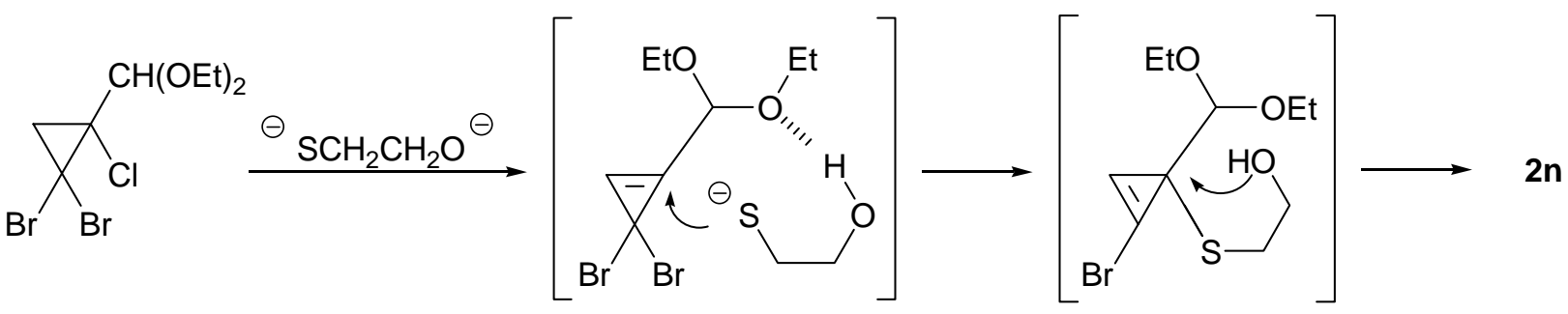

\section{Scheme 4}

The reaction involving 2-amionoethanol is a special case in the sense that the primary product, conceivably $N, O$-ketal 4 (a 1,3-oxazolidine), appears to be unstable under the reaction conditions and reacts further to furnish 1,1-diethoxy-3-butyn-2-one (2m). This secondary reaction is not surprising when the instability of $N, O$-ketals is taken into account. ${ }^{14}$ 
In conclusion, it has been substantiated that the regioselectivity of the ring opening of 1,1,2trihalocyclopropanes with a polar group $\mathrm{R}$ attached to $\mathrm{C}-2$ by protic reagents is strongly influenced by hydrogen bonding between $\mathrm{R}$ and the reagents. As a result attack at C-2 predominates in most cases and leads to formation of terminal alkynes.

\section{Experimental Section}

General Procedures. IR spectra were recorded on a Nicolet Impact 410 infrared spectrophotometer. NMR spectra were run on a Bruker Spectrospin AC $200 \mathrm{~F}$ or a Bruker Spectrospin DMX 400. Chemical shifts are reported downfield from TMS and coupling constants are given in Hz. GC analyses were performed on a HP 5890 Gas Chromatograph with a flame ionization detector and a HP Ultra 1 column (100\% dimethyl-polysiloxane, $25 \mathrm{~m}, 0.2$ $\mathrm{mm}$ i.d., $0.33 \mu \mathrm{m})$. Flash chromatography was carried out with Silica gel (230-400 mesh) as the stationary phase and mixtures of hexane and ethyl acetate as the mobile phase. The eluent composition is given in each case. TLC analyses of the reaction mixtures were performed with Silica gel $\left(60 \mathrm{~F}_{254}\right)$ on aluminium sheets with mixtures of hexane and ethyl acetate as the mobile phase. Mass spectra were obtained on a VG 7070 Micromass spectrometer, an Autospec Ultima mass spectrometer, a three-sector instrument with EBE geometry from Micromass Ltd Manchester, or JEOL AccuTOF T100GC, which were operated in the EI mode at $70 \mathrm{eV}$, the DART mode, or the CI mode as indicated for each spectrum. All boiling and melting points are uncorrected.

1,1-Dibromo-2-chloro-2-diethoxymethylcyclopropane (1a). The starting material for the synthesis of the cyclopropanes investigated, was prepared as described in the literature. ${ }^{7,8}$

\section{Synthesis of 1b-1h}

2,2-Dibromo-1-chlorocyclopropanecarbaldehyde (1b). A mixture of 1a (16.8 g, $64 \mathrm{mmol})$ and $80 \%$ aqueous formic acid $(250 \mathrm{~mL})$ was left stirring for $24 \mathrm{~h}$ at $50{ }^{\circ} \mathrm{C}$. The reaction mixture was extracted with $\mathrm{CH}_{2} \mathrm{Cl}_{2}(3 \times 250 \mathrm{~mL})$, and the combined organic extracts were washed with a saturated solution of $\mathrm{NaHCO}_{3}$ in $\mathrm{H}_{2} \mathrm{O}(500 \mathrm{~mL})$, and dried $\left(\mathrm{MgSO}_{4}\right)$. Distillation afforded $\mathbf{1 b}$ (15.3 g, 91\%), bp. $50^{\circ} \mathrm{C} / 0.5 \mathrm{~mm} \mathrm{Hg}$. IR (film): 3460 (w), 3084 (m), 2998 (w), 2851 (m), 2728 (w), 1727 (s), 1410 (m), 1272 (s), 1246 (m), 1181 (s), 1130 (m), 1028 (s), 995 (s), 963 (w), 881 (m), 860 (m), 822 (w), 694 (s), 641 (s) cm ${ }^{-1} ;{ }^{1} \mathrm{H}$ NMR $\left(200 \mathrm{MHz}, \mathrm{CDCl}_{3}\right): \delta 9.50$ (s, 1H), 2.82 (d, $J=9.3 \mathrm{~Hz}, 1 \mathrm{H}$, A part of an AB system), $2,18\left(\mathrm{~d}, J=9.3 \mathrm{~Hz}, 1 \mathrm{H}, \mathrm{B}\right.$ part of an AB system); ${ }^{13} \mathrm{C}$ NMR (50 MHz, $\mathrm{CDCl}_{3}$ ): $\delta$ 188.6, 53.1, 34.8, 26.9; MS (EI): m/z 260 (18), 246 (21), 231 (100), 171 (19), 159 (37), 145 (12), 128 (7), 57 (11); HRMS calcd for $[\mathrm{M}]^{+\cdot}\left(\left[\mathrm{C}_{4} \mathrm{H}_{3} \mathrm{Br}_{2} \mathrm{ClO}^{+}\right)\right.$ 259.8239 , found 259.8235 .

2,2-Dibromo-1-chlorocyclopropanecarboxylic acid (1c). A solution of $\mathrm{CrO}_{3}(1.77 \mathrm{~g}, 17.7$ $\mathrm{mmol})$ in a mixture of concentrated sulphuric acid $(1.6 \mathrm{~mL})$ and $\mathrm{H}_{2} \mathrm{O}(4.8 \mathrm{~mL})$ was slowly added 
to a mixture of $\mathbf{1 b}(2.6 \mathrm{~g}, 10 \mathrm{mmol})$ in acetone $(8 \mathrm{~mL})$, which was kept cool with an ice bath. After $1 \mathrm{~h}, \mathrm{H}_{2} \mathrm{O}(100 \mathrm{~mL})$ was added and the solution was made alkaline ( $\mathrm{pH}$ paper) by the addition of a $17 \%$ aqueous solution of $\mathrm{NaOH}$. The resulting mixture was extracted once with $\mathrm{CH}_{2} \mathrm{Cl}_{2}$. The aqueous phase was then made acidic ( $\mathrm{pH}$ paper) by adding $6 \mathrm{M} \mathrm{HCl}$, and extracted with $\mathrm{CH}_{2} \mathrm{Cl}_{2}$. The combined organic phases from the latter extraction were dried $\left(\mathrm{MgSO}_{4}\right)$ and concentrated. A solid was gradually formed, and this crude product was subsequently recrystallised from pentane to yield $1 \mathrm{c}(2.5 \mathrm{~g}, 91 \%)$ as pure white crystals, mp. $121-123{ }^{\circ} \mathrm{C}$. IR (KBr): $3720-2500$ (m), 3061 (w), 2982 (s), 2934 (m), 2901 (m), 2621 (w), 1717 (s), $1444(w)$, 1393 (m), 1370 (m), 1327 (m), 1268 (m), 1224 (m), 1153 (m), 1129 (s), 1089 (s), 1054 (s), 890 (w), 738 (m), 703 (m), 667 (w) cm ${ }^{-1} ;{ }^{1} \mathrm{H}$ NMR (200 MHz, $\left.\mathrm{CDCl}_{3}\right): \delta 10.00$ (s, 1H), $2.82(\mathrm{~d}, J=$ $9.5 \mathrm{~Hz}, 1 \mathrm{H}, \mathrm{A}$ part of an AB system), $2.10\left(\mathrm{~d}, J=9,5 \mathrm{~Hz}, 1 \mathrm{H}, \mathrm{B}\right.$ part of an AB system); ${ }^{13} \mathrm{C}$ NMR (50 MHz, $\mathrm{CDCl}_{3}$ ): $\delta$ 169.2, 48.1, 35.7, 26.7; MS (EI): m/z 279 (8), 261 (11), 233 (23), 199 (47), 171 (100), 161 (27), 153 (10), 141 (8), 135 (11), 117 (76), 107 (12), 89 (41), 79 (8), 73 (49), 61 (15); HRMS calcd. for $[\mathrm{M}]^{+} \cdot\left(\left[\mathrm{C}_{4} \mathrm{H}_{3} \mathrm{Br}_{2} \mathrm{ClO}_{2}\right]^{+}\right) 275.8188$, found 275.8180 .

Methyl 2,2-dibromo-1-chlorocyclopropanecarboxylate (1d). A solution of $\mathrm{CH}_{3} \mathrm{OH}(20 \mathrm{~mL})$, concentrated sulphuric acid $(12.0 \mathrm{~mL})$, and 1c $(1.4 \mathrm{~g}, 5.0 \mathrm{mmol})$ was refluxed for $12 \mathrm{~h}$. The reaction mixture was neutralised $(\mathrm{pH}$ paper) by adding a $10 \%(\mathrm{w} / \mathrm{w})$ aqueous solution of $\mathrm{NaHCO}_{3} . \mathrm{H}_{2} \mathrm{O}(100 \mathrm{~mL})$ was added and the resulting mixture was extracted with $\mathrm{CH}_{2} \mathrm{Cl}_{2}(3 \mathrm{x}$ $100 \mathrm{~mL})$. The combined organic phases were dried $\left(\mathrm{MgSO}_{4}\right)$, filtered, and concentrated. Flash chromatography (hexane:ethyl acetate, 97.5:2.5) afforded $1 \mathbf{d}(1.2 \mathrm{~g}, 82 \%)$ as a colourless oil. IR (film): 3502 (w), 3091 (w), 3006 (w), 2954 (w), 1746 (s), 1437 (s), 1412 (w), 1300 (s), 1234 (s), 1110 (m), 1065 (m), 1024 (s), 1003 (m), 934 (w), 857 (w), 731 (m), 694 (s) cm ${ }^{-1}$; ${ }^{1}$ H NMR (200 $\left.\mathrm{MHz}_{\mathrm{CDCl}}\right): \delta 3.89(\mathrm{~s}, 3 \mathrm{H}), 2.80(\mathrm{~d}, J=9.4 \mathrm{~Hz}, 1 \mathrm{H}, \mathrm{A}$ part of an AB stsem), $2.06(\mathrm{~d}, J=9,4$ $\mathrm{Hz}, 1 \mathrm{H}, \mathrm{B}$ part of an $\mathrm{AB}$ system); $\left.{ }^{13} \mathrm{C} \mathrm{NMR} \mathrm{(50} \mathrm{MHz,} \mathrm{CDCl}_{3}\right): \delta 164.2,53.5,48.4,35.2,26.9$; MS (EI): m/z 292 (2), 261 (10), 235 (20), 233 (30), 213 (70), 211 (52), 185 (100), 183 (72), 169 (10), 149 (20), 132 (30), $119(8), 89$ (12), 73 (40); HRMS calcd. for $[\mathrm{M}]^{+} \cdot\left(\left[\mathrm{C}_{5} \mathrm{H}_{5} \mathrm{Br}_{2} \mathrm{ClO}_{2}\right]^{+}\right)$ 289.8345 , found 289.8299 .

(2,2-Dibromo-1-chlorocyclopropyl)methanol (1e). $\mathrm{NaBH}_{4}(0.27 \mathrm{~g}, 7.3 \mathrm{mmol})$ was added to a solution of $\mathbf{1 b}(2.6 \mathrm{~g}, 10.0 \mathrm{mmol})$ in $\mathrm{CH}_{3} \mathrm{CH}_{2} \mathrm{OH}(50 \mathrm{~mL})$ and left stirring at $\mathrm{rt}$ for $10 \mathrm{~h}$. The reaction was quenched by adding $\mathrm{H}_{2} \mathrm{O}(50 \mathrm{~mL})$, and the resulting solution was extracted with $\mathrm{CH}_{2} \mathrm{Cl}_{2}(3 \times 50 \mathrm{~mL})$. The combined organic phases were dried $\left(\mathrm{MgSO}_{4}\right)$ and concentrated. Flash chromatography (hexane:ethyl acetate, 85:15) afforded $1 \mathrm{e}(2.2 \mathrm{~g}, 83 \%)$ as a colourless oil. IR (film): 3770-3050 (broad, s), 3625 (w), 3080 (m), 2998 (w), 2930 (m), 2877 (m), 1452 (m), 1417 (m), 1303 (m), 1283 (m), 1229 (m), 1149 (m), 1060 (s), 1009 (s), 925 (w), 899 (m), 850 (m), 737 (m), 705 (m), 695 (s), 648 (s), $624(\mathrm{~m}) \mathrm{cm}^{-1} ;{ }^{1} \mathrm{H}$ NMR (200 MHz, CDCl $): \delta$ 4.16-3.99 (m, 2H), $2.65(\mathrm{~m}, 1 \mathrm{H}), 2.09(\mathrm{~d}, J=9.3 \mathrm{~Hz}, 1 \mathrm{H}, \mathrm{A}$ part of an AB system), $2.02(\mathrm{~d}, J=9.3 \mathrm{~Hz}, 1 \mathrm{H}$, B part of and $\mathrm{AB}$ system); ${ }^{13} \mathrm{C} \mathrm{NMR}\left(50 \mathrm{MHz}, \mathrm{CDCl}_{3}\right): \delta 68.4,52.5,34.7,29.5 ; \mathrm{MS}(\mathrm{EI}): \mathrm{m} / \mathrm{z} 264(15)$, 248 (18), 234 (10), 187 (20), 169 (60), 157 (52), 151 (40), 123 (20), 121 (22), 103 (20), 82 (30), 78 (100), 73 (30); HRMS calcd. for $[\mathrm{M}]^{+} \cdot\left(\left[\mathrm{C}_{4} \mathrm{H}_{5} \mathrm{Br}_{2} \mathrm{ClO}\right]^{+}\right)$261.8396, found 261.8385. 
1-(2,2-Dibromo-1-chlorocyclopropyl)ethanol (1f). $\mathrm{CH}_{3} \mathrm{I}(2.0 \mathrm{~g}, 14.2 \mathrm{mmol})$ was slowly added to $\mathrm{Mg}(0.28 \mathrm{~g}, 12.0 \mathrm{mmol})$ in dry diethyl ether $(20 \mathrm{~mL})$. The mixture was refluxed for $30 \mathrm{~min}$ and cooled to rt. The methylmagnesium iodide solution was slowly added to a solution of $\mathbf{1 b}$ (2.6 $\mathrm{g}, 10.0 \mathrm{mmol}$ ) in dry diethyl ether at $0{ }^{\circ} \mathrm{C}$. After addition the reaction mixture was refluxed for an additional $30 \mathrm{~min}$ and was then quenched by adding saturated aqueous $\mathrm{NH}_{4} \mathrm{Cl}(20 \mathrm{~mL})$. The hydrolysate was extracted with diethyl ether $(3 \times 20 \mathrm{~mL})$, and the combined organic phases were dried $\left(\mathrm{MgSO}_{4}\right)$ and concentrated. Flash chromatography (hexane:ethyl acetate, 80:20) afforded 1f $(2.42 \mathrm{~g}, 88 \%)$ as a colorless oil. IR (film): 3800-3050 (s), 3078 (w), 2982 (s), 2958 (w), 2931 (s), $2870(\mathrm{w}), 1446(\mathrm{~m}), 1420(\mathrm{~m}), 1375(\mathrm{~m}), 1267(\mathrm{~m}), 1173(\mathrm{~m}), 1110(\mathrm{~m}), 1076(\mathrm{~m}), 1031(\mathrm{w})$, $1001(\mathrm{~m}), 949(\mathrm{w}), 916(\mathrm{~m}), 824(\mathrm{w}), 699(\mathrm{~m}) \mathrm{cm}^{-1} ;{ }^{1} \mathrm{H}$ NMR $\left(200 \mathrm{MHz}, \mathrm{CDCl}_{3}\right): \delta 4.00$ (quintet, $J=6.4 \mathrm{~Hz}, 1 \mathrm{H}), 2.29(\mathrm{~d}, J=6.4 \mathrm{~Hz}, 1 \mathrm{H}), 2.02(\mathrm{~d}, J=9.3 \mathrm{~Hz}, 1 \mathrm{H}, \mathrm{A}$ part of an AB system), $1.93\left(\mathrm{~d}, J=9.3 \mathrm{~Hz}, 1 \mathrm{H}, \mathrm{B}\right.$ part of and AB system), $1.45(\mathrm{~d}, J=6,4 \mathrm{~Hz}, 3 \mathrm{H}) ;{ }^{13} \mathrm{C}$ NMR (50 MHz; $\mathrm{CDCl}_{3}$ ): $\delta$ 68.4, 52.5, 34.7, 29.5, 14.8; MS (EI): m/z 276 (12), 274 (22), 260 (12), 201 (10), 183 (20), 181 (30), 153 (42), 128 (12), 103 (25), 82 (100); HRMS calcd. for [M] ${ }^{+}$. $\left(\left[\mathrm{C}_{5} \mathrm{H}_{7} \mathrm{Br}_{2} \mathrm{ClO}\right]^{+}\right)$275.8552, found 275.8564 .

1-(2,2-Dibromo-1-chlorocyclopropyl)ethanone (1g). A solution of $\mathrm{CrO}_{3}(1.77 \mathrm{~g}, 17.7 \mathrm{mmol})$, concentrated sulphuric acid $(1.6 \mathrm{~mL})$, and $\mathrm{H}_{2} \mathrm{O}(4.8 \mathrm{~mL})$ was slowly added to a mixture of $\mathbf{1 f}$ $(2.78 \mathrm{~g}, 10.0 \mathrm{mmol})$ and acetone $(8 \mathrm{~mL})$ kept on ice bath. After stirring for $4 \mathrm{~h}$, water $(50 \mathrm{~mL})$ was added and the product mixture was extracted with $\mathrm{CH}_{2} \mathrm{Cl}_{2}(3 \times 50 \mathrm{~mL})$. The combined organic phases were dried $\left(\mathrm{MgSO}_{4}\right)$ and concentrated. Flash chromatography (hexane:ethyl acetate, 97.5:2.5) afforded 1g (2.0 g, 73\%) as a colourless oil. IR (film): 3448 (w), 3087 (w), 3003 (w), 2925 (w), 1723 (m), 1417 (m), 1387 (w), 1359 (m), 1276 (m), 1205 (w), 1059 (w), 1030 (m), 1012 (m), 931 (w), 801 (w), 699 (m), 624m, 610m cm $\left.{ }^{-1} ;{ }^{1} \mathrm{H} \mathrm{NMR} \mathrm{(200} \mathrm{MHz;} \mathrm{CDCl}_{3}\right)$ : $\delta 2.79(\mathrm{~d}, J=9.1 \mathrm{~Hz}, 1 \mathrm{H}, \mathrm{A}$ part of an AB system), $2.55(\mathrm{~s}, 3 \mathrm{H}), 1.96(\mathrm{~d}, J=9.1 \mathrm{~Hz}, 1 \mathrm{H}$, B part of an $\mathrm{AB}$ system); ${ }^{13} \mathrm{C} \mathrm{NMR}\left(50 \mathrm{MHz} ; \mathrm{CDCl}_{3}\right): \delta 198.6,53.1,34.8,27.0,14.9$; MS (EI): $\mathrm{m} / \mathrm{z} 277$ (12), 233 (30), 197 (88), 169 (52), 153 (9), 131 (16), 116 (100), 107 (8), 87 (27), 73 (52), 61 (7); HRMS calcd. for $[\mathrm{M}]^{+} \cdot\left(\left[\mathrm{C}_{5} \mathrm{H}_{5} \mathrm{Br}_{2} \mathrm{ClO}\right]^{+}\right)$273.8396, found 273.8385 .

2-(2,2-Dibromo-1-chlorocyclopropyl)-1,3-dithiolane (1h). Procedure 1. A mixture of 1a (6.7 g, $20 \mathrm{mmol})$, 1,2-ethanedithiol $(2.0 \mathrm{~mL}, 25 \mathrm{mmol})$, and silica chloride $(3.0 \mathrm{~g}, 30 \mathrm{mmol})$ in $\mathrm{CH}_{2} \mathrm{Cl}_{2}(50 \mathrm{~mL})$ was stirred at $\mathrm{rt}$ for $4 \mathrm{~h}$. The silica chloride was removed by filtration and washed with $\mathrm{CH}_{2} \mathrm{Cl}_{2}(50 \mathrm{~mL})$. The organic phase was washed with $10 \%(\mathrm{w} / \mathrm{w})$ aqueous $\mathrm{NaOH}$ $(50 \mathrm{~mL}), \mathrm{H}_{2} \mathrm{O}(100 \mathrm{~mL})$, dried over $\mathrm{MgSO}_{4}$ and concentrated. Flash chromatography (hexane:ethyl acetate, 90:10) afforded $\mathbf{1 h}(5.3 \mathrm{~g}, 78 \%)$ as a colourless oil.

Procedure 2. ${ }^{12}$ Aldehyde $\mathbf{1 b}(2.6 \mathrm{~g}, 10 \mathrm{mmol})$ and 1,2-ethanedithiol (1.6 mL, $\left.20 \mathrm{mmol}\right)$ was dissolved in $\mathrm{CHCl}_{3}(50 \mathrm{~mL})$ and stirred for $1 \mathrm{~h}$ at $20{ }^{\circ} \mathrm{C}$. The reaction mixture was then cooled to $0{ }^{\circ} \mathrm{C}$ and boron trifluoride diethyl etherate $(2.0 \mathrm{~mL}, \sim 3.8 \mathrm{M})$ was added dropwise over $10 \mathrm{~min}$. The reaction mixture was then stirred at $0{ }^{\circ} \mathrm{C}$ for further $12 \mathrm{~h}$. The reaction mixture was washed with $10 \%(\mathrm{w} / \mathrm{w})$ aqueous $\mathrm{NaOH}(20 \mathrm{~mL}), \mathrm{H}_{2} \mathrm{O}(20 \mathrm{~mL})$, aqueous saturated $\mathrm{NaCl}(20 \mathrm{~mL})$ and dried over $\mathrm{MgSO}_{4}$. The solvent was evaporated and flash chromatography (hexane:ethyl acetate, 90:10) afforded $\mathbf{1 h}(2.6 \mathrm{~g}, 78 \%)$ as a colourless oil. 
1h. IR (film): 3080 (w), 2978 (s), 2930 (m), 2897 (m), 2881 (m), 1480 (w), 1444 (m), 1422 (m), 1372 (s), 1354 (m), 1295 (w), 1268 (m), 1248 (m), 1184 (s), 1108 (s), 1072 (s), 1010 (m), 964 $(\mathrm{w}), 702(\mathrm{~m}), 668(\mathrm{~m}), 629(\mathrm{~m}) \mathrm{cm}^{-1}$; ${ }^{1} \mathrm{H}$ NMR $\left(200 \mathrm{MHz} ; \mathrm{CDCl}_{3}\right): \delta 4.85(\mathrm{~s}, 1 \mathrm{H}), 3.60-3.47(\mathrm{~m}$, 2H), 3.37-3.26 (m, 2H), 2,15 (d, $J=9.4 \mathrm{~Hz}, 1 \mathrm{H}$, A part of an AB system), $2.08(\mathrm{~d}, J=9.4 \mathrm{~Hz}$, $1 \mathrm{H}, \mathrm{B}$ part of and $\mathrm{AB}$ system); ${ }^{13} \mathrm{C} \mathrm{NMR}\left(50 \mathrm{MHz} ; \mathrm{CDCl}_{3}\right): \delta 61.4,40.1,39.8,38.1,31.8,30.4$; MS (EI): m/z 336 (9), 275 (11), 243 (14), 185 (30), 176 (12), 141 (12), 123 (7), 111 (10), 103 (74), 75 (100), 67 (9); HRMS calcd. for $[\mathrm{M}]^{+} \cdot\left(\left[\mathrm{C}_{6} \mathrm{H}_{7} \mathrm{Br}_{2} \mathrm{ClS}_{2}\right]^{+}\right), 335.8044$, found 335.8051.

\section{Ring opening of 1b-1h under PTC in the presence of ethanol. General procedure}

To a cold $\left(0{ }^{\circ} \mathrm{C}\right)$ mixture of one of the 1,1-dibromo-2-chlorocyclopropane derivatives $\mathbf{1 b}-\mathbf{1 h}$, TEBA, and $\mathrm{CH}_{3} \mathrm{CH}_{2} \mathrm{OH}$ in $\mathrm{CH}_{2} \mathrm{Cl}_{2}(25-50 \mathrm{~mL})$ was added $50 \%(\mathrm{w} / \mathrm{w})$ aqueous $\mathrm{NaOH}$. The cooling bath was removed and the reaction mixture was stirred vigorously at room temperature until all the starting material was consumed (monitored TLC). Water was added, the products were extracted with dichloromethane, and the combined extracts were dried with magnesium sulfate, filtered and evaporated under vacuum. The products, except from 1c, were isolated from the residue by flash chromatography.

To aldehyde $1 \mathbf{b}(1.3 \mathrm{~g}, 5.0 \mathrm{mmol})$, TEBA $(0.2 \mathrm{~g})$ and $\mathrm{CH}_{3} \mathrm{CH}_{2} \mathrm{OH}(0.92 \mathrm{~g}, 20.0 \mathrm{mmol})$ in $\mathrm{CH}_{2} \mathrm{Cl}_{2}(25 \mathrm{~mL})$ was added $\mathrm{NaOH}(2.1 \mathrm{~mL}, 40 \mathrm{mmol})$ dropwise during $15 \mathrm{~min}$ and the reaction mixture stirred for further $24 \mathrm{~h}$. At this point all the starting material was consumed $\mathrm{H}_{2} \mathrm{O}(25$ $\mathrm{mL}$ ) was added and the reaction mixture was extracted with $\mathrm{CH}_{2} \mathrm{Cl}_{2}(3 \times 25 \mathrm{~mL})$. The combined organic extracts were combined, dried $\left(\mathrm{MgSO}_{4}\right)$ and concentrated to yield a reaction crude product of $0.8 \mathrm{~g}$. Chromatographic investigation showed a complex reaction mixture that contained at least 12 products from which we were not able to isolate reasonably pure samples any of the components (see text).

To acid 1c (1.4 g, $5.0 \mathrm{mmol})$, TEBA (0.2 g) and $\mathrm{CH}_{3} \mathrm{CH}_{2} \mathrm{OH}(0.92 \mathrm{~g}, 20.0 \mathrm{mmol})$ in $\mathrm{CH}_{2} \mathrm{Cl}_{2}$ (25 $\mathrm{mL})$ was added $\mathrm{NaOH}(2.1 \mathrm{~mL}, 40 \mathrm{mmol})$ dropwise during $15 \mathrm{~min}$ and the reaction mixture stirred for further $24 \mathrm{~h} . \mathrm{H}_{2} \mathrm{O}(25 \mathrm{~mL})$ was added and the water phase was washed with $\mathrm{CH}_{2} \mathrm{Cl}_{2}(3$ $\mathrm{x} 25 \mathrm{~mL})$. The water phase was then made slightly acidic $(\sim 4, \mathrm{pH}$ paper) with $2 \mathrm{M} \mathrm{HCl}$ and then extracted with $\mathrm{CH}_{2} \mathrm{Cl}_{2}(3 \times 25 \mathrm{~mL})$. Evaporation of the solvent gave 2,2-diethoxybut-3-ynoic acid (2c) (0.65 g, 75\%) as a semisolid which melted gradually when heated.

2c. IR (film): 3750- 2550 (m), 3252 (w), 2980 (s), 2931 (s), 2889 (m), 2628 (w), 2115 (w), 1714 (s), 1441 (m), 1396 (m), 1371 (w), 1265 (m), 1220 (m), 1153 (m), 1120 (s), 1081 (s), 1054 (s), $890(\mathrm{~m}), 733$ (w) $700(\mathrm{w}) ;{ }^{1} \mathrm{H}$ NMR $\left(200 \mathrm{MHz}, \mathrm{CDCl}_{3}\right): \delta 9.28(\mathrm{~s}, 1 \mathrm{H}), 3.90-3.42(\mathrm{~m}, 4 \mathrm{H}), 2.62$ $(\mathrm{s}, 1 \mathrm{H}), 1.29-1.05(\mathrm{~m}, 6 \mathrm{H}) ;{ }^{13} \mathrm{C} \mathrm{NMR}\left(50 \mathrm{MHz}, \mathrm{CDCl}_{3}\right): \delta 173.1,100.1,83.2,79.1,63.0,15.0$; MS (EI): m/z 173 (30), 172 (40), 127 (55), 103 (100), 60 (12), 45 (15) m/z; HRMS calcd. for [M$\mathrm{OEt}]^{+}\left(\left[\mathrm{C}_{6} \mathrm{H}_{7} \mathrm{O}_{3}\right]^{+}\right) 127.0402$ found 127.0410 .

To ester 1d (1.5 g, $5.0 \mathrm{mmol})$, TEBA $(0.2 \mathrm{~g})$ and $\mathrm{CH}_{3} \mathrm{CH}_{2} \mathrm{OH}(0.92 \mathrm{~g}, 20 \mathrm{mmol})$ in $\mathrm{CH}_{2} \mathrm{Cl}_{2}(25$ $\mathrm{mL})$ was added $\mathrm{NaOH}(2.1 \mathrm{~mL}, 40 \mathrm{mmol})$ dropwise during $15 \mathrm{~min}$ and the reaction mixture stirred for further $20 \mathrm{~h}$. Water $(25 \mathrm{~mL})$ was added and the two phases were separated. The water phase was extracted with $\mathrm{CH}_{2} \mathrm{Cl}_{2}(3 \times 25 \mathrm{~mL})$ and the combined organic extracts were dried 
$\left(\mathrm{MgSO}_{4}\right)$, filtered and concentrated. Methyl 2,2-diethoxybut-3-ynoate (2d) (0.7 g, 75\%) was isolated as an light yellow oil by flash chromatography (hexane:ethyl acetate, 90:10).

2d. IR (film): 3304 (m), 2979 (s), 2931 (s), 2900 (s), 2113 (w), 1741 (s), 1630 (m), 1592 (m), 1478 (m), 1444 (m), 1418 (m), 1392 (m), 1356 (m), 1261 (s), 1219 (m), 1114 (s), 1067 (s), 962 (m), $867(\mathrm{~m}), 806(\mathrm{~m}), 758(\mathrm{~s}), 701(\mathrm{~m}), 666(\mathrm{~m}) \mathrm{cm}^{-1} ;{ }^{1} \mathrm{H}$ NMR $\left(200 \mathrm{MHz}, \mathrm{CDCl}_{3}\right): \delta 3.92(\mathrm{~s}$, $3 \mathrm{H}), 3.81-3.67(\mathrm{~m}, 4 \mathrm{H}), 2.61(\mathrm{~s}, 1 \mathrm{H}), 1.29-1.17(\mathrm{~m}, 6 \mathrm{H}) ;{ }^{13} \mathrm{C} \mathrm{NMR}\left(50 \mathrm{MHz}, \mathrm{CDCl}_{3}\right): \delta 172.4$, 104.6, 79.2, 73.2, 60.8, 53.5, 17.9; MS (EI): m/z 271 (20\%), 241 (8), 213 (48), 195 (32), 181 (18), 167 (7), 145 (22), 111 (6), 103 (100), 75 (49), 63 (13), 57 (20); HRMS calcd. for [M-OEt] $\left(\left[\mathrm{C}_{4} \mathrm{H}_{14} \mathrm{O}_{4}\right]^{+}\right)$141.055, found 141.0552 .

To alcohol 1e (2.6 g, $10.0 \mathrm{mmol})$, TEBA $(0.2 \mathrm{~g})$ and $\mathrm{CH}_{3} \mathrm{CH}_{2} \mathrm{OH}(1.84 \mathrm{~g}, 40.0 \mathrm{mmol})$ in $\mathrm{CH}_{2} \mathrm{Cl}_{2}$ was added $\mathrm{NaOH}(4.2 \mathrm{~mL}, 80 \mathrm{mmol})$ dropwise during $15 \mathrm{~min}$, and the reaction mixture stirred for another $20 \mathrm{~h}$. Water $(50 \mathrm{~mL})$ was added and the two phases were separated. The water phase was extracted with $\mathrm{CH}_{2} \mathrm{Cl}_{2}(3 \times 50 \mathrm{~mL})$ and the combined organic extracts were dried $\left(\mathrm{MgSO}_{4}\right)$, filtered and concentrated. Two products were formed in a 1:1 ratio (NMR analysis). Isolation by flash chromatography (hexane:ethyl acetate, 90:10) yielded 2,2-diethoxybut-3-yn-1-ol (2e) (0.65 $\mathrm{g}, 41 \%)$ as an oil and 4,4-diethoxybut-2-yn-1-ol (3e) (0.65 g, 41\%), also as an oil.

2e. IR (film): 3650-3090 (s), 3263 (s), 2989 (s), 2934 (s), 2893 (s), 2114 (m), 1480 (m), 1445 (m), 1392 (s), 1337 (m), 1262 (s), 1186 (s), 1135 (s), 1080 (s), 947 (s), 918 (m), 860 (m), 732 (m), $697(\mathrm{~m}), 662(\mathrm{~m}) \mathrm{cm}^{-1} ;{ }^{1} \mathrm{H}$ NMR $\left(200 \mathrm{MHz}, \mathrm{CDCl}_{3}\right): \delta 3.80-3.65(\mathrm{~m}, 6 \mathrm{H}), 2.64(\mathrm{~s}, 1 \mathrm{H}), 2.25$ $(\mathrm{m}, 1 \mathrm{H}), 1.27-1.16(\mathrm{~m}, 6 \mathrm{H}) ;{ }^{13} \mathrm{C} \mathrm{NMR}\left(50 \mathrm{MHz}, \mathrm{CDCl}_{3}\right): \delta 96.8,78.7,74.1,65.6,58.8,14.9$; MS (EI): m/z 186 (6), 179 (17), 168 (9), 155 (12), 141 (17), 127 (68), 113 (80), 99 (35), 85 (55), 71 (100), 53 (39); HRMS calcd. for $[\mathrm{M}]^{+} \cdot\left(\left[\mathrm{C}_{8} \mathrm{H}_{14} \mathrm{O}_{3}\right]^{+}\right) 158.0942$, found 158.0938.

3e. IR (film): 3670-3140 (m), 2977 (m), 2931 (m), 2889 (m), 2180 (w), 1732 (w), 1714 (w), 1627 (w), 1481 (w), 1445 (m), 1391 (m), 1370 (m), 1329 (m), 1269 (m), 1141 (s), 1081 (s), 1051 (s), $951(\mathrm{~m}), 912(\mathrm{~m}), 821(\mathrm{w}), 737(\mathrm{~m}), 702(\mathrm{~m}), 666(\mathrm{~m}) \mathrm{cm}^{-1} ;{ }^{1} \mathrm{H} \mathrm{NMR}\left(200 \mathrm{MHz}, \mathrm{CDCl}_{3}\right): \delta$ $5.31(\mathrm{~s}, 1 \mathrm{H}), 4.32$ (broad s, 2H), 3.80-3.55 (m, 4H), 2.23 (broad s, 1H), 1.24 (t, J=7.3 Hz, 6H); ${ }^{13} \mathrm{C} \mathrm{NMR}\left(50 \mathrm{MHz}, \mathrm{CDCl}_{3}\right): \delta 96.8,81.6,78.6,58.8,51.3,15.0 ; \mathrm{MS}$ (EI): $\mathrm{m} / \mathrm{z} 179$ (1), 141 (11), 127 (72), 113 (85), 105 (80), 99 (35), 85 (55), 71 (100); HRMS calcd. for [M-OEt] ${ }^{+}\left(\left[\mathrm{C}_{8} \mathrm{H}_{14} \mathrm{O}_{3}\right]^{+}\right)$ 158.0942, found 158.0944 .

To alcohol 1f $(0.74 \mathrm{~g}, 2.68 \mathrm{mmol})$, TEBA $(0.05 \mathrm{~g})$ and $\mathrm{CH}_{3} \mathrm{CH}_{2} \mathrm{OH}(0.50 \mathrm{~g}, 10.71 \mathrm{mmol})$ in $\mathrm{CH}_{2} \mathrm{Cl}_{2}(40 \mathrm{~mL})$ was added $\mathrm{NaOH}(1.1 \mathrm{~mL}, 21.4 \mathrm{mmol})$ dropwise during $15 \mathrm{~min}$, and the reaction mixture stirred for further $30 \mathrm{~h}$. Water $(40 \mathrm{~mL})$ was added and the two phases were separated. The water phase was extracted with $\mathrm{CH}_{2} \mathrm{Cl}_{2}(3 \mathrm{x} 40 \mathrm{~mL})$ and the combined organic extracts were combined, dried $\left(\mathrm{MgSO}_{4}\right)$, filtered and concentrated. 5,5-Diethoxypent-3-yn-2-ol (3f) $(0.40 \mathrm{~g}, 87 \%)$ was isolated as an light yellow oil by flash chromatography (hexane:ethyl acetate, $85: 15)$.

3f. IR (reflectance): 3650-3120 (w), 2977 (m), 2886 (m), 2244 (w), 1445 (m), 1369 (m), 1326 (m), 1150 (s), 1047 (s), 1005 (s), 914 (m), 886 (m), 834 (w), 793 (w) cm ${ }^{-1}$; ${ }^{1}$ NMR (200 MHz, $\left.\mathrm{CDCl}_{3}\right): \delta 5.30(\mathrm{~s}, 1 \mathrm{H}), 4.56(\mathrm{~m}, 1 \mathrm{H}), 3.78-3.50(\mathrm{~m}, 4 \mathrm{H}), 2.35(\mathrm{~d}, J=4.7 \mathrm{~Hz}, 1 \mathrm{H}), 1.47(\mathrm{~d}, J=$ $6.6 \mathrm{~Hz}, 3 \mathrm{H}), 1.24(\mathrm{t}, J=6.5 \mathrm{~Hz}, 6 \mathrm{H}) ;{ }^{13} \mathrm{C} \mathrm{NMR}\left(50 \mathrm{MHz}, \mathrm{CDCl}_{3}\right): \delta 91.1,87.2,79.0,60.8,58.0$, 
23.8, 14.9; MS (DART): m/z; 253 (50), 145 (75), 127 (100), 99 (90), 81 (70); HRMS calcd. for $[\mathrm{M}-\mathrm{OEt}]^{+}\left(\left[\mathrm{C}_{7} \mathrm{H}_{11} \mathrm{O}_{2}\right]^{+}\right) 127.07590$, found 127.06884 .

To ketone $1 \mathrm{~g}$ ( $2.2 \mathrm{~g}, 8.0 \mathrm{mmol})$, TEBA $(0.2 \mathrm{~g})$ and $\mathrm{CH}_{3} \mathrm{CH}_{2} \mathrm{OH}(1.47 \mathrm{~g}, 32 \mathrm{mmol})$ in $\mathrm{CH}_{2} \mathrm{Cl}_{2}(50$ $\mathrm{mL})$ was added $\mathrm{NaOH}(3.4 \mathrm{~mL}, 64 \mathrm{mmol})$ dropwise during $15 \mathrm{~min}$ and the reaction mixture stirred for further $20 \mathrm{~h}$. Water $(50 \mathrm{~mL})$ was added and the two phases were separated. The water phase was extracted with $\mathrm{CH}_{2} \mathrm{Cl}_{2}(3 \times 50 \mathrm{~mL})$ and the combined organic extracts were dried $\left(\mathrm{MgSO}_{4}\right)$, filtered and concentrated. 3,3-Diethoxypent-4-yn-2-one (2g) (1.0 g, 75\%) was isolated as an oil by flash chromatography (hexane:ethyl acetate, 90:10).

2g. IR (film): 3246 (w), 2979 (s), 2931 (m), 2900 (m), 2113 (w), 1741 (s), 1592 (w), 1444 (w), 1418 (w), 1392 (w), 1356 (m), 1261 (s), 1219 (m), 1114 (s), 962 (w), 867 (w), 806 (m), 758 (s), $666(\mathrm{~m}) \mathrm{cm}^{-1} ;{ }^{1} \mathrm{H}$ NMR $\left(200 \mathrm{MHz}, \mathrm{CDCl}_{3}\right): \delta 3.87-3.53(\mathrm{~m}, 4 \mathrm{H}), 2.65(\mathrm{~s}, 1 \mathrm{H}), 2.05(\mathrm{~s}, 3 \mathrm{H}), 1.31-$ $1.15(\mathrm{~m}, 6 \mathrm{H}) ;{ }^{13} \mathrm{C}$ NMR $\left(50 \mathrm{MHz}, \mathrm{CDCl}_{3}\right): \delta 181.2,100.6,81.8,79.0,62.7,15.0 ; \mathrm{MS}(\mathrm{EI}): \mathrm{m} / \mathrm{z}$ 279 (30), 167 (43), 157 (6), 149 (100), 127 (6), 113 (11), 83 (6), 75 (45), 57 (31); HRMS calcd. for $[\mathrm{M}+\mathrm{H}]^{+}\left(\left[\mathrm{C}_{9} \mathrm{H}_{14} \mathrm{O}_{3}\right]^{+}\right) 171.0977$, found 171.0971.

To dithiolane 1h $(3.4 \mathrm{~g}, 10 \mathrm{mmol})$, TEBA $(0.4 \mathrm{~g})$ and $\mathrm{CH}_{3} \mathrm{CH}_{2} \mathrm{OH}(1.8 \mathrm{~g}, 40 \mathrm{mmol})$ in $\mathrm{CH}_{2} \mathrm{Cl}_{2}$ $(50 \mathrm{~mL})$ was added $\mathrm{NaOH}(4.2 \mathrm{~mL}, 80 \mathrm{mmol})$ dropwise over $15 \mathrm{~min}$ and the reaction mixture stirred for further $24 \mathrm{~h}$. Water $(50 \mathrm{~mL})$ was added and the two phases were separated. The water phase was extracted with $\mathrm{CH}_{2} \mathrm{Cl}_{2}(3 \times 25 \mathrm{~mL})$ and the combined organic extracts were dried $\left(\mathrm{MgSO}_{4}\right)$, filtered and concentrated. 2-(1,1-Diethoxypropyl-2-ynyl)-1,3-dithiolane (2h) (1.2 g, $51 \%$ ) was isolated as an oil by flash chromatography (hexane:ethyl acetate, 90:10).

2h. IR (film): 3242 (m), 2983 (s), 2935 (m), 2909 (m), 2876 (m), 2095 (w), 1479 (m), 1465 (m), 1447 (m), 1374 (s), 1300 (m), 1161 (w), 1098 (m), 1048 (s), 938 (w), 847 (m), 634 (m), 607 (m) $\mathrm{cm}^{-1}$; ${ }^{1} \mathrm{H}$ NMR $\left(200 \mathrm{MHz}, \mathrm{CDCl}_{3}\right): \delta 4.42(\mathrm{~s}, 1 \mathrm{H}), 4.19-4.10(\mathrm{~m}, 4 \mathrm{H}), 3.93-3.46(\mathrm{~m}, 4 \mathrm{H}), 2.58(\mathrm{~s}$, $1 \mathrm{H}), 1.30(\mathrm{t}, J=7.2 \mathrm{~Hz}, 6 \mathrm{H}) ;{ }^{13} \mathrm{C} \mathrm{NMR}\left(50 \mathrm{MHz}, \mathrm{CDCl}_{3}\right): \delta 102.8,78.5,76.2,58.1,52.0,38.9$, 14.9; MS (EI): m/z 207 (12), 190 (43), 187 (18), 127 (50), 105 (100), 87 (11), 73 (20); HRMS calcd. for $[\mathrm{M}]^{+} \cdot\left(\left[\mathrm{C}_{10} \mathrm{H}_{16} \mathrm{O}_{2} \mathrm{~S}_{2}\right]^{+}\right)$232.0592, found 232.0589 .

Ring opening of 1a under PTC in the presence of an alcohol or a thiol. General procedure To a cold $\left(0{ }^{\circ} \mathrm{C}\right)$ mixture of 1a, TEBA and either $\mathrm{CH}_{3} \mathrm{OH},\left(\mathrm{CH}_{3}\right)_{2} \mathrm{CHOH},\left(\mathrm{CH}_{3}\right)_{3} \mathrm{COH}$, $\mathrm{HOCH}_{2} \mathrm{CH}_{2} \mathrm{OH}, \mathrm{H}_{2} \mathrm{NCH}_{2} \mathrm{CH}_{2} \mathrm{OH}, \mathrm{HSCH}_{2} \mathrm{CH}_{2} \mathrm{OH}$, or $\mathrm{HSCH}_{2} \mathrm{CH}_{2} \mathrm{SH}$ in $\mathrm{CH}_{2} \mathrm{Cl}_{2}$ was added $50 \%$ $(\mathrm{w} / \mathrm{w})$ aqueous $\mathrm{NaOH}$. The cooling bath was removed and the reaction mixture was stirred vigorously at room temperature until all the starting material was consumed (monitored by TLC). Water was added, the products were extracted with ether, and the combined extracts were dried with magnesium sulfate, filtered and evaporated under vacuum. The products were isolated from the residue by flash chromatography.

Methanol; formation of 4,4-diethoxy-3,3-dimethoxybut-1-yne (2i). Cyclopropane 1a (2.0 g, $6.0 \mathrm{mmol})$ was dissolved in a solution of $\mathrm{CH}_{2} \mathrm{Cl}_{2}(25 \mathrm{~mL})$, methanol $(0.82 \mathrm{~g}, 25.5 \mathrm{mmol})$ and TEBA (0.2 g). NaOH (2.5 mL, $48 \mathrm{mmol})$ was added dropwise during $15 \mathrm{~min}$ and the reaction mixture stirred for further $24 \mathrm{~h}$. Water $(25 \mathrm{~mL})$ was added and the two phases were separated. The water phase was extracted with $\mathrm{CH}_{2} \mathrm{Cl}_{2}(3 \times 25 \mathrm{~mL})$ and the combined organic extracts were combined, dried $\left(\mathrm{MgSO}_{4}\right)$, filtered and concentrated. 4,4-Diethoxy-3,3-dimethoxybut-1-yne (2i) 
$(1.1 \mathrm{~g}, 96 \%)$ was isolated as an oil from the reaction mixture with flash chromatography (hexane:ethyl acetate, 90:10). IR (film): 3259 (m), 2977 (s), 2941 (s), 2906 (m), 2835 (m), 2115 (w), 1740 (m), 1466 (m), 1446 (w), 1392 (m), 1373 (m), 1331 (m), 1296 (w), 1243 (m), 1113 (s), 1085 (s), 980 (m), 902 (w), $654(\mathrm{~m}) \mathrm{cm}^{-1} ;{ }^{1} \mathrm{H}$ NMR (200 MHz; $\left.\mathrm{CDCl}_{3}\right): \delta 4.43(\mathrm{~s}, 1 \mathrm{H}), 3.86-3.63$ $(\mathrm{m}, 4 \mathrm{H}), 3.46(\mathrm{~s}, 6 \mathrm{H}), 2.65(\mathrm{~s}, 1 \mathrm{H}), 1,27(\mathrm{t}, J=7,1 \mathrm{~Hz}, 6 \mathrm{H}) ;{ }^{13} \mathrm{C} \mathrm{NMR}\left(50 \mathrm{MHz} ; \mathrm{CDCl}_{3}\right): \delta$ 102.4, 98.3, 77.1, 75.0, 64.2, 51.1, 14,9; MS (EI): m/z 201 (8), 177 (35), 157 (90), 141 (5), 115 (20), 103 (15), 98 (70), 97 (100), 75 (90), 69 (60), 59 (40), 55 (40); HRMS calcd. for [M-OEt] $\left(\left[\mathrm{C}_{8} \mathrm{H}_{13} \mathrm{O}_{3}\right]^{+}\right)$157.0865, found 157.0863 .

Isopropyl alcohol; formation of 4,4-diethoxy-3,3-diisopropoxybut-1-yne (2j). Cyclopropane 1a $(2.0 \mathrm{~g}, 6.0 \mathrm{mmol})$ was dissolved in a solution of $\mathrm{CH}_{2} \mathrm{Cl}_{2}(25 \mathrm{~mL})$, isopropyl alcohol $(1.5 \mathrm{~g}$, $25.0 \mathrm{mmol})$ and TEBA $(0.2 \mathrm{~g})$. $\mathrm{NaOH}(2.5 \mathrm{~mL}, 48 \mathrm{mmol})$ was added dropwise during $15 \mathrm{~min}$ and the reaction mixture stirred for further $24 \mathrm{~h}$. Water $(25 \mathrm{~mL})$ was added and the two phases were separated. The water phase was extracted with $\mathrm{CH}_{2} \mathrm{Cl}_{2}(3 \times 25 \mathrm{~mL})$ and the combined organic extracts were combined, dried $\left(\mathrm{MgSO}_{4}\right)$, filtered and concentrated. 4,4-Diethoxy-3,3diisopropoxybut-1-yne (2j) $(0.6 \mathrm{~g}, 39 \%)$ was isolated from the reaction mixture with flash chromatography (hexane:ethyl acetate, 90:10). IR (film): 3311 (m), 3257 (m), 2976 (s), 2931 (s), 2899 (s), 2112 (m), 1727 (m), 1481 (m), 1467 (m), 1455 (m), 1445 (m), 1393 (s), 1381 (s), 1328 (m), 1296 (m), 1273 (m), 1217 (m), 1110 (s), 1078 (s), 981 (m), 912 (m), 896 (m), 715 (m), 699 (m) $\mathrm{cm}^{-1} ;{ }^{1} \mathrm{H}$ NMR $\left(200 \mathrm{MHz} ; \mathrm{CDCl}_{3}\right): \delta 4.32$ (septet, $\left.J=6.2 \mathrm{~Hz}, 2 \mathrm{H}\right), 4.17(\mathrm{~s}, 1 \mathrm{H}), 3.83-3.57$ $(\mathrm{m}, 4 \mathrm{H}), 2.60(\mathrm{~s}, 1 \mathrm{H}), 1.28-1.16(\mathrm{~m}, 18 \mathrm{H}) ;{ }^{13} \mathrm{C} \mathrm{NMR}\left(50 \mathrm{MHz} ; \mathrm{CDCl}_{3}\right): \delta 104.9,99.0,78.6$, 75.4, 68.5, 65.3, 65.1, 59.4, 23.7, 23.5, 15.1; MS (EI): m/z 287 (10), 259 (5), 213 (10), 199 (25), 185 (20), 158 (22), 155 (40), 129 (10), 103 (100), 83 (25), 75 (60); HRMS calcd. for [M] ${ }^{+}$. $\left(\left[\mathrm{C}_{14} \mathrm{H}_{26} \mathrm{O}_{4}\right]^{+}\right)$258.1831, found 258.1828 .

tert-Butyl alcohol; no reaction. Cyclopropane 1a (3.4 g, $10.0 \mathrm{mmol})$ was dissolved in a solution of $\mathrm{CH}_{2} \mathrm{Cl}_{2}(50 \mathrm{~mL})$, tert-butyl alcohol $(3.0 \mathrm{~g}, 40.0 \mathrm{mmol})$ and TEBA $(0.4 \mathrm{~g})$. NaOH $(4.2 \mathrm{~mL}, 80$ mmol) was added dropwise during $15 \mathrm{~min}$. After a total reaction time of $48 \mathrm{~h}$ the reaction was stopped when TLC and GC showed no conversion of the starting compound. Some water was added and the reaction mixture was worked up. No product was obtained, just unreacted starting material.

Ethylene glycol; formation of 2-(diethoxymethyl)-2-ethynyl-1,3-dioxolane (2l). Cyclopropane 1a $(3.4 \mathrm{~g}, 10.0 \mathrm{mmol})$ was dissolved in a solution of $\mathrm{CH}_{2} \mathrm{Cl}_{2}(50 \mathrm{~mL})$, ethylene glycol $(1.2 \mathrm{~g}$, $20.0 \mathrm{mmol})$ and TEBA $(0.4 \mathrm{~g})$. $\mathrm{NaOH}(4.2 \mathrm{~mL}, 80 \mathrm{mmol})$ was added dropwise during $15 \mathrm{~min}$ and the reaction mixture was stirred for further $24 \mathrm{~h}$. Water $(50 \mathrm{~mL})$ was added and the two phases were separated. The water phase was extracted with $\mathrm{CH}_{2} \mathrm{Cl}_{2}(3 \times 25 \mathrm{~mL})$ and the combined organic extracts were combined, dried $\left(\mathrm{MgSO}_{4}\right)$, filtered and concentrated. Diethoxymethyl-2-ethynyl-1,3-dioxolane (2l) (0.85 g, 43\%) was isolated from the reaction mixture by flash chromatography (hexane:ethyl acetate, 90:10). IR (film): 3260 (s), 2977 (s), 2930 (s), 2897 (s), 2113 (m), 1446 (m), 1372 (s), 1344 (m), 1202 (m), 1116 (s), 1074 (s), 1039 (m), $950(\mathrm{~m}), 903(\mathrm{~m}), 837(\mathrm{w}), 699(\mathrm{~m}), 668(\mathrm{~m}) \mathrm{cm}^{-1} ;{ }^{1} \mathrm{H}$ NMR $\left(200 \mathrm{MHz} ; \mathrm{CDCl}_{3}\right): \delta 4.43(\mathrm{~s}$, $1 \mathrm{H}), 4.18-4.02(\mathrm{~m}, 4 \mathrm{H}), 3.88-3.64(\mathrm{~m}, 4 \mathrm{H}), 2.57(\mathrm{~s}, 1 \mathrm{H}), 1.30-1.18(\mathrm{~m}, 6 \mathrm{H}) ;{ }^{13} \mathrm{C} \mathrm{NMR}(50 \mathrm{MHz}$; 
$\left.\mathrm{CDCl}_{3}\right): \delta 102.4,101.3,78.7,72.7,64.9,64.3,15.1 ; \mathrm{MS}(\mathrm{EI}): \mathrm{m} / \mathrm{z} 201$ (10), 155 (20), 149 (28), 127 (22), 103 (100), 75 (50); HRMS calcd. for [M-OEt $]^{+}\left(\left[\mathrm{C}_{8} \mathrm{H}_{11} \mathrm{O}_{3}\right]^{+}\right)$155.0710, found 155.0718 .

2-Aminoethanol; formation of 1,1-diethoxybut-3-yn-2-one (2m). Cyclopropane $1 \mathrm{a}(2.0 \mathrm{~g}, 6.0$ mmol) was dissolved in a solution of $\mathrm{CH}_{2} \mathrm{Cl}_{2}(25 \mathrm{~mL}), 2$-aminoethanol $(0.7 \mathrm{~g}, 12.0 \mathrm{mmol})$ and TEBA (0.2 g). NaOH (2.5 mL, $48 \mathrm{mmol})$ was added dropwise during $15 \mathrm{~min}$ and the reaction mixture was stirred for further $24 \mathrm{~h}$. Water $(25 \mathrm{~mL})$ was added and the two phases were separated. The water phase was extracted with $\mathrm{CH}_{2} \mathrm{Cl}_{2}(3 \times 25 \mathrm{~mL})$ and the combined organic extracts were dried $\left(\mathrm{MgSO}_{4}\right)$, filtered and concentrated. 1,1-Diethoxybut-3-yn-2-one (2m) (0.39 g, 42\%) was isolated as an oil from the reaction mixture by flash chromatography (hexane:ethyl acetate, 90:10). The spectroscopic data were in accordance with those published in the literature with one exception, the proton NMR spectrum. ${ }^{7}$ The chemical shift of the acetylenic proton in $2 \mathbf{m}$ has been reported to be $2.66 \mathrm{ppm},{ }^{7}$ but it should be $3.39 \mathrm{ppm}$; thus the complete proton NMR spectrum is as follows: ${ }^{1} \mathrm{H} \mathrm{NMR}\left(\mathrm{CDCl}_{3}, 200 \mathrm{MHz}\right): \delta 1.27(\mathrm{t}, J=7.1 \mathrm{~Hz}, 6 \mathrm{H}), 3.39(\mathrm{~s}, 1 \mathrm{H}), 3.47-$ $3.95(\mathrm{~m}, 4 \mathrm{H}), 4.68(\mathrm{~s}, 1 \mathrm{H})$.

2-Mercaptoethanol; formation of 2-diethoxymethyl-2-ethynyl)-1,3-oxathiolane (2n). Cyclopropane 1a $(3.4 \mathrm{~g}, 10.0 \mathrm{mmol})$ was dissolved in a mixture of $\mathrm{CH}_{2} \mathrm{Cl}_{2}(50 \mathrm{~mL})$, 2mercaptoethanol (1.3 g, $20.0 \mathrm{mmol})$ and TEBA $(0.4 \mathrm{~g})$. NaOH $(4.2 \mathrm{~mL}, 80 \mathrm{mmol})$ was added during $15 \mathrm{~min}$ and the reaction mixture was stirred for further $24 \mathrm{~h}$. Water $(25 \mathrm{~mL})$ was added and the two phases were separated. The water phase was extracted with $\mathrm{CH}_{2} \mathrm{Cl}_{2}(3 \times 25 \mathrm{~mL})$ and the combined organic extracts were combined, dried $\left(\mathrm{MgSO}_{4}\right)$, filtered and concentrated. 2Diethoxymethyl-2-ethynyl-1,3-oxathiolane (2n) (1.0 g, 51\%) was isolated from the reaction mixture with flash chromatography (hexane:ethyl acetate, 90:10). IR (film): 3259 (m), 2976 (s), 2934 (m), 2900 (s), 2111 (m), 1724 (m), 1467 (m), 1446 (m), 1381 (s), 1368 (s), 1328 (s), 1295 (m), $1274(\mathrm{~m}), 1120$ (s), $1070(\mathrm{~s}), 984(\mathrm{~m}), 952(\mathrm{~m}), 937(\mathrm{~m}), 904(\mathrm{~m}), 838(\mathrm{~m}), 780(\mathrm{w}), 697$ (m), $650(\mathrm{~m}) ;{ }^{1} \mathrm{H}$ NMR $\left(200 \mathrm{MHz} ; \mathrm{CDCl}_{3}\right): \delta 4.66(\mathrm{~s}, 1 \mathrm{H}), 3.97(\mathrm{~m}, 2 \mathrm{H}), 3.82-3.60(\mathrm{~m}, 4 \mathrm{H})$, 3.06-2.88 (m, 2H), $2.55(\mathrm{~s}, 1 \mathrm{H}), 1.28-1.10(\mathrm{~m}, 6 \mathrm{H}) ;{ }^{13} \mathrm{C} \mathrm{NMR}\left(50 \mathrm{MHz} ; \mathrm{CDCl}_{3}\right): \delta 104.8,99.8$, 82.1, 65.4, 63.8, 60.1 , 48.2, 15.1; MS (EI): m/z 171 (20), 163 (10), 113 (100), 75 (30), 45 (20); HRMS calcd. for [M-OEt $]^{+}\left(\left[\mathrm{C}_{8} \mathrm{H}_{11} \mathrm{O}_{2} \mathrm{~S}\right]^{+}\right) 171.0482$ found 171.0487 .

1,2-Ethanedithiol; no reaction. Cyclopropane 1a (3.4 g, $10.0 \mathrm{mmol})$ was dissolved in a solution of $\mathrm{CH}_{2} \mathrm{Cl}_{2}$ (50 mL), 1,2-ethanedithiol (1.9 g, $\left.20.0 \mathrm{mmol}\right)$ and TEBA (0.4 g). NaOH (4.2 mL, 80 $\mathrm{mmol}$ ) was added dropwise during $15 \mathrm{~min}$. After $48 \mathrm{~h}$ the reaction was stopped since TLC and GC analysis showed no conversion of the starting compound. Some water was added and the reaction mixture was worked up to recover the starting cyclopropane.

\section{Supplementary Information Available}

The ${ }^{1} \mathrm{H}-\mathrm{NMR}$ and ${ }^{13} \mathrm{C}-\mathrm{NMR}$ spectra of all new compounds are compiled as supplementary material and are available from the authors on request. 


\section{Acknowledgements}

Financial support from Norsk Hydro is gratefully acknowledged. Thanks are also due to Ann M. Whyatt at the University of Bergen, and Dr. Dag Ekeberg at the Norwegian University of Life Sciences, for skillful technical assistance.

\section{References}

1. Sydnes, L. K.; Bakstad, E. Acta Chem. Scand. 1996, 50, 446.

2. Sydnes, L. K.; Bakstad, E. Acta Chem. Scand. 1997, 51, 1132.

3. Bakstad, E.; Sydnes, L. K. Acta Chem. Scand. 1998, 52, 1029.

4. Bakstad, E.; Olsen, A. S.; Sandberg, M.; Sydnes, L. K. Acta Chem. Scand. 1999, 53, 465.

5. Sydnes, L. K. Eur. J. Chem. 2000, 3511.

6. Sydnes, L. K.; Alnes, K. F. S.; Erdogan, N. Chem. Monthly 2006, 12, 345.

7. Sydnes, L. K.; Holmelid, B.; Kvernenes, O. H.; Sandberg, M.; Hodne, M.; Bakstad, E. Tetrahedron 2007, 63, 4144.

8. Sydnes, L. K.; Kvernenes, O. H. Org. Synth. 2005, 83, 184.

9. Seyferth, D.; Prokai, B. J. Org. Chem. 1966, 31, 1702.

10. Nefedov, O. M.; Agavelyan, E. S. Izv. Akad. Nauk SSSR, Ser. Khim. 1974, 838; Chem. Abstr. 1974, 81, 37308e.

11. Firouzabadi, H.; Iranpoor, N.; Karimi, B.; Hazarkani, H. Synlett 2000, 263.

12. Tietze, L. F.; Eicher, T. Reactions and Synthesis in the Organic Chemistry Laboratory; University Science Books: Mill Valley, CA, USA, 1989, p 105.

13. (a) March, J. Advanced Organic Chemistry; Reactions, Mechanisms, and Structure, $3^{\text {rd }}$ Edn.; Wiley: New York, 1985, pp 218-223. (b) Carey, F. A.; Sundberg, R. J. Advanced Organic Chemistry; Part A: Structure and Mechanisms, $4^{\text {th }}$ Edn.; Kluwer Academic/Plenum Publishers: New York, 2000, pp 243-246.

14. Kocienski, P. J. Protecting Groups; Georg Thieme Verlag: Stuttgart, 1994, p 218. 